\title{
Gender, household headship and children's educational performance in Nigeria: debunking the myth of poor performance in female-headed households
}

\author{
Funmi Bammeke \\ Department of Sociology, University of Lagos \\ Akoka, Lagos, Nigeria \\ Email: funmibammeke@yahoo.co.uk; obammeke@unilag.edu.ng
}

\section{Abstract}

This study examines how gender interacts with household headship to influence children's educational performance. It evaluates the educational performance of children in senior secondary schools in Lagos, Nigeria by whether they live in male or female-headed households. The study shows no significant statistical difference in the performance of children in male and female-headed households, but shows that parents' educational level, especially women's formal education, influences their children's educational performance. The study reveals that children's educational performance is also dependent on support factors in the household. It also shows that though women heading households without partners may experience more constraint in terms of resources, they often strive to ensure that their children do not fulfill society's expectation of poor performance. The study concludes on the need to empower household heads if their children must access knowledge, an important measure of human development.

Key words: Gender, household, household headship, children, educational performance

\section{Résumé}

Cette étude examine comment le sexe réagit réciproquement avec l'autorité de ménage pour influencer de l'exécution des enfants éducatives. II évalue l'exécution éducative d'enfants dans les écoles secondaires supérieures dans Lagos, Nigéria par s'ils habitent en les ménages de mâle ou femelle-dirigé. L'étude ne montre pas de différence statistique significative dans l'exécution d'enfants dans les ménages de mâle et femelle-dirigé, mais les spectacles que les parents > le niveau éducatif, l'éducation des femmes surtout formelle, influence leur exécution des enfants éducative. L'étude révèle cette exécution des enfants éducative est aussi dépendante sur les facteurs de soutien dans le ménage. II montre aussi que bien que les femmes dirigeant des ménages sans les partenaires peuvent éprouver plus de contrainte sur le plan des ressources, ils efforcent se garantir souvent que leurs enfants ne remplissent pas l'espérance de la société d'exécution pauvre. L'étude conclut sur le besoin de donner pouvoir têtes au ménage si leurs enfants doivent accéder à la connaissance, une mesure importante de développement humain. 
Mots clés : Le sexe, le ménage, l'autorité de ménage, les enfants, l'exécution educative

\section{Introduction}

The household as a locus of biological and social reproduction is relevant to the lives of all individuals. The composition of the household including the ages, number and sex of members is central to any analysis of the household. Also crucial to the understanding of the behaviour of members of the household are the opportunities and constraints experienced by individual members. Gender influences not only perceptions of the household and relationship between members, but also the opportunities and constraints of individual members of the household. Socially constructed differences between men and women, cultural expectations and stereotypes of masculinity and femininity foster differences between men and women heading households.

In many societies, patriarchy is considered the norm. Based on this, headship of the household is associated with men. The social and cultural recognition of men as household head earns them support from individuals and institutions in this respect. This recognition is lacking for women heading households; whose households are perceived as deviation from the norm. Often with lower education, lower income and lower social status, women heading households usually do so from a disadvantaged position. In addition to these, there are assumptions of their inability to raise well-adjusted children, especially where they have no partner. The expected mal-adjustment of children in female-headed households is assumed to manifest in several areas including their educational performance.

Do children in male-headed households have better educational performance than their counterparts in femaleheaded households or are there other factors influencing the educational performance of children? Are there differences in the opportunities and constraints of children in male and female-headed households which are actually indicative of wider gender inequities?

\section{Literature review and theoretical framework}

The literature on gender, development and planning gives prominence to woman-headed households as households in need of special attention because of the observed relationship between female headship and poverty (Buvinic and Gupta 1993:24). However, identifying women-headed households is problematic. A major problem is the fact that respondents giving information in census or survey questionnaires almost always mention the eldest male as head. Also in many cases, the woman who, in fact, heads a household may not be recognized as such and may not name herself as such because of cultural prescription identifying men with household authority. The result of this is that most census data reflect the conventional assumption that a woman will be recognized as head only if she had no resident male partner.

Although scholars have not answered the question on the significance of female-headed households, 
they have been unequivocal about their relatively small number. Bongaarts (200I:14) noted in his household surveys in different regions of the world that the majority of household heads were men but that the proportion of households headed by women was substantial in all regions: 13 percent in the Near East/North Africa, 16 percent in Asia, 22 percent in sub-Saharan Africa, and 24 percent in Latin America. He noted that in countries such as Ghana, Haiti, Kenya and Zimbabwe, the proportion exceeds one-third.

In Nigeria, the multiple indicator cluster survey of 1995 as presented by the Federal Office of Statistics showed that one in eight household heads (12.5\%) was a woman. The proportion of female-headed households in Nigeria however appears to be rising steadily. The Nigerian Demographic and Health Survey (1999) shows that femaleheaded households now constitute 17 percent while male-headed households constitute 83 percent. When disaggregated by sector, urban areas still lead in the proportion of female-headed households with 19 percent, while rural areas record 16 percent (NPC (Nigeria) 2000). The Nigerian Demographic and Health Survey (2003) indicate that male-headed households constitute 83.4 percent while femaleheaded households are 16.6 percent. The rural-urban distribution is 15 percent and 19 percent respectively (NPC (Nigeria) 2004).

Female-headed households are as different as the circumstances surrounding their emergence. Many scholars have observed the heterogeneous nature of female-headed households (e.g. Barros et al. 1997, Varley 1996,
Kennedy and Peters 1992, and the Federal Office of Statistics 1996) and this heterogeneity may contribute to the problem of identification. Some common characteristics of female-headed households include the tendency for the households to be over represented among the poor (Barros et al. 1997), lack of free time and leisure, and relatively lower education. Female-headed households are also likely to be smaller in size than male-headed households and are also likely to have smaller numbers of adults and children. The main cause of the smaller number of adults has been attributed to the fact that female heads very rarely co-reside with a spouse, while the majority of male heads live with their wives (Bongaarts, 200I).

The increasing awareness of the centrality of gender in the lives of people has led to explanations on the differences between men and women. Scholars have sought to explain why virtually every society differentiates people on the basis of gender; why gender often forms the basis for the division of labour and why virtually every known society is based on male domination and women and men's tasks valued differently (Kimmel 2000:2). Arguments about gender differences have been rooted in biology, culture, materialist position and the patriarchal ideology.

Functionalists use the biological differences between men and women to justify gender inequality in the society; while the conflict perspective attributes inequality to social and cultural arrangements and not nature. In spite of its perceived shallowness, the conflict perspective might offer some explanations in relation to the differences between 
men and women heading households. The fact that headship is culturally defined may explain why the eldest male in a household is almost always designated head even when data identifying economic responsibilities show otherwise. Closely related to this, it can be argued that social and cultural expectations often dictate the behaviour of men and women with respect to the performance of household responsibilities.

Feminist theories of gender inequality argue that men and women are not only differently situated in society but are also unequally situated. Specifically, they argued that women get less of the material resources, social status, power and opportunities for self actualization than men who share their social location - be it a location based on class, race, occupation, ethnical, religion, education, nationality or any other significant factor. The theories are useful in proffering explanations for differences in the social status, opportunities and access to material resources by men and women heading households. Unlike theorists of gender differences, theorists of gender inequality believe that it is possible to change the situation, which makes women less empowered than men (Lengermann and Niebrugge - Brantley 1993: 318).

One of the propositions of Blumberg's theory of gender stratification and gender and development is relevant to the explanation of men/women's responsibilities in relation to their income. The proposition is that men tend to spend income under their control differently from women who have provider responsibilities (even as providers of the last resort) with women focusing more on children's well-being and family subsistence (Blumberg and Pethan 1994:6). This proposition has been supported by Chindime and Ubomba-Jaswa (2007:48) who found that children in female-headed households tend to have better nutritional outcomes than those in male-headed households despite the tendency of female-headed households to be poorer. Their explanation for this finding is that women are more likely to spend their income on food and child welfare while men spend more on personal consumption and on agricultural inputs. The policy implication of Blumberg's proposition which is also applicable to Chindime and Ubomba-Jaswa's finding is that where income from a developing project is channeled only to men as heads of families it is likely that families will lose benefits that would have come to them through women's more welfare-focused spending patterns.

The voices of African scholars are discernible in the gender discourse. Oyewunmi (1997) challenges major assumptions of the gender discourse including the universalization of gender as a fundamental organizing principle in all societies and across time (BakareYusuf 2004). She argues against gender being the dominant mode of power everywhere. Among the Yoruba for example, she argues that seniority rather than gender is the dominant mode of power. She has however been criticized for not considering the interwoven nature of power dynamics and therefore not being able to account for the complexity and nuances of seniority as it operates among the Yoruba (Bakare-Yusuf 2004:69). Beyond ques- 
tioning the assumptions of the gender discourse, African scholars have clear positions on the subject. Nzegwu (200I) emphasizes the need to articulate the cultural basis of female empowerment in indigenous societies and make them available for use by modern women. She examines a conception of equality in a dual-sex system in which sex differences are factored into an understanding of human worth with the aim of understanding what counts as equality when women and men are conceived as social complements, and social roles and responsibilities define gender identity. She contrasts the precolonial conception of equality explicated from a dual-sex system with one that is explicated from a mono-sex system to determine the socio- political condition of women under each system so as to ascertain which structure accords greater respect to women.

Ekejiuba's (1995) contribution to the gender discourse in Africa is profound. Her childhood experience of women as initiators of development and active participants of social and economic processes in their communities contrasts with the western concept of women as being 'marginalized, downtrodden, and exploited by patriarchy and motherhood'. Her dissatisfaction with the inadequacy of the household concept relative to her perception of West African rural society led her to the submission that the concept of the 'hearth-hold' which is centred around the mother rather than the household is the basic unit of agricultural production in many African societies. Based on the realities of rural West African societies, she argues for a woman-centred unit of social analysis which focuses on women's activities and organization and perceives their relationships and roles as both catalysts and full beneficiaries of development.

\section{Data and methods}

The main study from which this article is extracted took place in Badagry, Mainland and Surulere local government areas of Lagos State, Nigeria. It gathered data that were both quantitavely and qualitatively analysed. Data obtained from the survey were analysed quantitavely while data obtained from focus group discussions and indepth interview with female heads were analysed qualitatively. This presentation, however, focuses on data from 209 children from Badagry and Mainland, on whom academic tests were administered, as well as the heads of their households.

\section{Sampling procedure}

One co-educational senior secondary school was purposively selected in each local government area. In each school, children respondents were selected from senior secondary I through a random sampling technique. In Badagry, a total of 67 students were selected while in Mainland, the selected students were 150. The selected 217 students were interviewed and invited to participate in tests in English and Mathematics meant to measure their educational performance. Following the children's interview and the administration of test, their households were visited and the head of household (or a responsible adult who may be a spouse or partner) was interviewed. Headship was decided based on preliminary questions on who performed which responsibility in the 
household, who took major decisions and who exercised moral authority. Only 209 household heads could be interviewed from the 217 children's households. Only such household heads and their children are included in this presentation. Data were collected from the children and household heads using structured questionnaires. The Household Head and Spouses' Questionnaire (HHSQ) had 97 questions and sought to gather information on the socio-economic background of respondents including sex, age, marital status, educational level, residence pattern, income, occupation and time usage. Other questions were on the structure of household and household responsibilities. The Children's Questionnaire (CQ) had 30 questions and sought to gather information on the background of the children including age, sex, class, ethnic group, residence pattern, birth placement, and perception of headship among others. Others were on the performance of household responsibilities and parental involvement in children's education.

The choice of the subjects was deliberate. English and Mathematics are compulsory for all students and without a credit in both they cannot obtain admission into tertiary institutions. The English Test Questionnaire (ETQ) and the Mathematics Test Questionnaire (MTQ) were therefore meant to evaluate the students' ability in the two important subjects. The contents of the test were based on the approved curriculum common to the schools. In order to further obtain a content validation of the questions, assessors who were teachers of the chosen subjects were asked to evaluate each question and determine the extent to which it was a valid measure of the concept being tested.

\section{Results}

Structure and characteristics of households

About two-thirds (69.4 percent) of the investigated households were maleheaded while only one-third (30.6 percent) was female-headed. This confirms the predominance of male-headed households as documented in the literature (Bongaarts 200I). The study found a number of differences in the structure and characteristics of male and female headed households. The mean age of male household heads (47.88) was higher than that of their female counterparts (43.95). Female-headed households tend to be smaller than male-headed households as the mean number of persons who live in maleheaded households is 7.23 compared with 6.33 in female-headed households. The mean number of children in maleheaded households is 5.17 whereas it is 4.64 in female-headed households. This confirms that female-headed households tend to have fewer children than male-headed households. Male household heads are predominantly married (88.3 percent) while more than half of female heads (56.0) have marital status other than married (e.g. widowed, separated or divorced). Even those who are married do not live with their partners. This validates an earlier finding by Bongaarts (200I) who attributed the smaller size of female-headed households to the fact that female household heads rarely co-reside with a spouse whereas the majority of male heads live with their wives. The limitation of their 
resources may also restrain female heads from taking in relations. The educational levels attained by male and female household heads are similar although more males (43.4 percent) than females (39.I percent) have higher education. Female heads have lower income than male heads that also tend to have partners/spouses engaged in income generating activities unlike female heads who are predominantly without partners.

Male and female household heads in the study spend comparable time on their income generating activities but female heads spend more time on domestic duties than their male counterparts. The representation of female heads increases as the number of hours spent on domestic duties increases. More than half of female heads $(57.9$ percent) spend above three hours on domestic duties while close to half of male heads(46.9 percent) have no domestic duties. This is sufficient reason for female heads not to have as much leisure as their male counterparts. Household heads in the study are predominantly rent paying tenants (67.6 and 64.I percent of male and female heads respectively pay rent). The majority occupies multiroom apartments in which a household or family lives in one or more rooms. Multi room residences are often characterized by crowding and sharing of facilities. More female headed households (56.3 percent) live in these residences compared with 43.4 percent of maleheaded households. The reverse is the case with larger accommodation where there is more privacy and households have more spatial autonomy in terms of grounds available for their use. More male-headed households ( $3 \mathrm{I}$.I percent) live in such residences compared with 28. I percent of female-headed households. More male-headed households (25.5 percent) compared to femaleheaded households (I5.6 percent) occupy blocks of flats which are characterized by exclusive use of facilities and are more expensive than multiroom apartments. There is a wider gap in terms of the ownership of means of transportation with three quarters (75 percent) of female heads owing no means of transportation compared with over half (55.9) of male heads.

Responsibilities of household heads

A consideration of the responsibilities of household heads shows that they are responsible for tangible, financially measurable responsibilities as well as less tangible and less measurable responsibilities which often tend to be more time consuming. Male heads of households however tend to have more support than female heads for the tangible responsibilities. The study shows that household heads predominantly bear responsibility for house rent, school fees, hospital bills, electricity bills, purchase of children's school books and uniforms and attendance of parent-teachers' meetings. For these various responsibilities, between 20 and over 38 percent of male heads indicated that the responsibilities were performed with their spouses. However only between $1 \mathrm{I}$ and 17 percent of female heads performed these responsibilities with their partners. Joint involvement of male heads and partners is more dominant than heads' sole involvement in the purchase of children's other clothing, supervision of school work and hospital runs. These 
responsibilities were solely borne by female heads in their households. The study also shows greater involvement of female heads in time consuming responsibilities such as school runs and laundry. There are gendered patterns in some responsibilities as the table shows that household shopping and cooking are done predominantly by spouses of male heads and female heads. Activities such as fetching of water, washing of dishes and other cleaning tasks are done predominantly by older children and relatives. What is apparent in terms of household responsibilities is that female heads of households often bear tangible responsibilities borne by male heads but because they are often without partners, they also bear non-tangi- ble responsibilities borne by spouses of male heads.

\section{Gender of household head and children's educational performance}

The result of the tests administered on children whose household heads are being investigated shows that the assumption that children in a particular household would perform better than those in other households is not true for all circumstances. Table I shows the distribution of children respondents by mean scores in English Language, Standard Deviation and Standard Error by type of household.

Table I Distribution of children respondents by mean scores in English Language, Standard Deviation (SD) and Standard Error by type of household headship

\begin{tabular}{cccccc} 
& $\begin{array}{c}\text { Type of Household } \\
\text { Headship }\end{array}$ & $N$ & $\begin{array}{c}\text { Mean } \\
\text { Score }\end{array}$ & $\begin{array}{c}\text { Std. } \\
\text { Deviation }\end{array}$ & $\begin{array}{c}\text { Std. Error } \\
\text { Mean }\end{array}$ \\
$\begin{array}{c}\text { Total score for English } \\
\text { test }\end{array}$ & Male headed & 145 & 51.00 & 13.66 & 1.13 \\
& Female headed & 64 & 51.63 & 14.40 & 1.80 \\
\hline
\end{tabular}

Although the table shows that children in male-headed households have a mean score of 51.00 in English language while those in Female-headed households have a mean score of 51.63 , the ttest for equality of means (see Table 2) shows that the mean difference of -63 is not statistically significant at $95 \%$ interval. We assume equal variances because of the lack of statistical significance $(p>0.05)$.

Table 2 T-test for equality of means in English Language

\begin{tabular}{|c|c|c|c|c|c|c|}
\hline & \multicolumn{2}{|c|}{$\begin{array}{l}\text { Levene's Test } \\
\text { for Equality of } \\
\text { Variance }\end{array}$} & \multicolumn{4}{|c|}{ t-test for equality of means } \\
\hline & $\mathrm{F}$ & Sig. & $\mathrm{t}$ & $\mathrm{df}$ & Sig (2 tailed) & Mean \\
\hline & \multicolumn{6}{|c|}{ Difference } \\
\hline $\begin{array}{l}\text { Total score for Equal } \\
\text { English test variances } \\
\text { assumed }\end{array}$ & .003 & .959 & -300 & 207 & .765 & -.63 \\
\hline
\end{tabular}


ics, Standard Deviation, and Standard Error by type of household, also shows differences in the mean scores. Children in male-headed households have a mean score of 49.24 in Mathematics, while those in female-headed households have a mean score of 54.30 .

Table 3 Distribution of children respondents by mean scores in Mathematics,

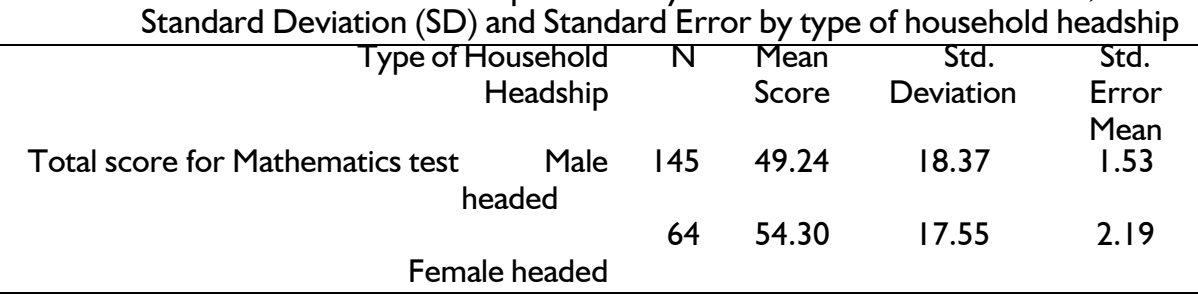

Table 4 however shows that the mean difference of -5.06 is not statistically significant. The table also shows that the variances in the scores for Mathematics are equal for children in both households because of the lack of statistical significance $(p>0.05)$. The decision rule is to assume equal variances if the probability value is not statistically significant.

Table 4 T-test for equality of means in Mathematics

\begin{tabular}{|c|c|c|c|c|c|c|}
\hline \multirow[b]{3}{*}{$\begin{array}{l}\text { Total score for } \\
\text { Math test }\end{array}$} & \multirow[b]{3}{*}{$\begin{array}{c}\text { Equal } \\
\text { variances } \\
\text { assumed }\end{array}$} & \multicolumn{2}{|l|}{$\begin{array}{l}\text { Levene's Test } \\
\text { for Equality of } \\
\text { Variance }\end{array}$} & \multicolumn{3}{|c|}{ t-test for equality of means } \\
\hline & & Sig. & $\mathrm{t}$ & df & $\begin{array}{l}\text { Sig ( } 2 \text { tailed }) \\
\text { Difference }\end{array}$ & Mean \\
\hline & & .396 .530 & -1.859 & 207 & .065 & -5.06 \\
\hline
\end{tabular}

Although not statistically significant, the data shows that for both school subjects, children in female-headed households have higher mean scores than those in male-headed households. The meaning of the result is that the differences in the academic performance of the children respondents are not serious enough to permit a prediction that children in one household perform better than those in the other. However it is surprising that the children of femaleheaded households did not perform more poorly but rather tended towards a higher (although not significant) performance. This debunks the stereotype that children in female-headed households will exhibit maladjustment in their educational performance.

\section{Household head's level of education and children's educational performance}

This study shows a positive relationship between parents' level of education and children's educational performance measured by their scores in the tests. Table 5 shows that the higher the level of parental education, the higher the mean scores of children in both English and Mathematics. The computed analysis of variance (ANOVA) shows that the difference in the scores of the children for English by parent's level of education is significant $(F=4.818, \quad d f=3$, 
$\mathrm{p}<0.01)$. That of Mathematics is also significant $(F=2.960, d f=3, p<0.05)$. The relationship is however stronger for English than for Mathematics, as reflected in the $p$ values (See Table 6).

Table 5 Distribution of children respondents by mean scores in English Language and Mathematics, S.D., Std. Error of Mean and Analysis of Variance (ANOVA) by Parents' Highest Level of Education

\begin{tabular}{|c|c|c|c|}
\hline $\begin{array}{c}\text { Parent's } \\
\text { Highest level } \\
\text { of Education }\end{array}$ & & $\begin{array}{l}\text { Children's } \\
\text { Total Score } \\
\text { For English }\end{array}$ & $\begin{array}{l}\text { Children's } \\
\text { Total Score for } \\
\text { Mathematics }\end{array}$ \\
\hline $\begin{array}{l}\text { No formal } \\
\text { Education }\end{array}$ & $\begin{array}{c}\text { Mean Score } \\
N \\
\text { Std. Dev. } \\
\text { Std. Error } \\
\text { of mean }\end{array}$ & $\begin{array}{c}35.63 \\
8 \\
12.082 \\
4.272\end{array}$ & $\begin{array}{c}35.00 \\
8 \\
13.628 \\
4.818\end{array}$ \\
\hline $\begin{array}{l}\text { Primary } \\
\text { Education }\end{array}$ & $\begin{array}{c}\text { Mean Score } \\
N \\
\text { Std. Dev. } \\
\text { Std. Error } \\
\text { of mean }\end{array}$ & $\begin{array}{c}47.94 \\
34 \\
\mid 4.777 \\
2.534\end{array}$ & $\begin{array}{c}47.34 \\
34 \\
17.591 \\
3.017\end{array}$ \\
\hline $\begin{array}{l}\text { Secondary } \\
\text { Education }\end{array}$ & $\begin{array}{c}\text { Mean Score } \\
N \\
\text { Std. Dev. } \\
\text { Std. Error } \\
\text { of mean }\end{array}$ & $\begin{array}{c}52.43 \\
76 \\
13.626 \\
1.563\end{array}$ & $\begin{array}{c}51.32 \\
76 \\
16.028 \\
1.839\end{array}$ \\
\hline $\begin{array}{l}\text { Higher } \\
\text { Education }\end{array}$ & $\begin{array}{c}\text { Mean Score } \\
N \\
\text { Std. Dev. } \\
\text { Std. Error } \\
\text { of mean }\end{array}$ & $\begin{array}{c}52.74 \\
91 \\
12.987 \\
1.361\end{array}$ & $\begin{array}{c}53.02 \\
91 \\
19.859 \\
2.082\end{array}$ \\
\hline Total & $\begin{array}{c}\text { Mean Score } \\
N \\
\text { Std. Dev. } \\
\text { Std. Error } \\
\text { of mean }\end{array}$ & $\begin{array}{c}51.19 \\
209 \\
13.86 \mid \\
.959\end{array}$ & $\begin{array}{c}50.79 \\
209 \\
18.233 \\
1.26\end{array}$ \\
\hline
\end{tabular}

ANOVA: English $F=4.818, \mathrm{df}=3, \mathrm{p}<0.01$

Mathematics $F=2.960, d f=3, p<0.05$

When the tests' scores were further disaggregated by sex of parents by level of education, similar patterns emerged. The scores of children in both subjects increased as the level of education of their parent increased. The study underscores the importance of formal education for women, because except for those who had no formal education, Tables $6 \mathrm{a}$ and Table $6 \mathrm{~b}$ show that the scores of children whose mothers were the responsible adults were higher at every level of education than those of children whose fathers were the responsible adults. For both male and female responsible adults, the gaps in the scores of children were wider between those whose parents had no formal education and those who had primary education than they were among those whose parents had some measure of education (primary, second- 
ary or higher). However, when the only the differences in the mean scores mean scores were disaggregated by in Mathematics were significant education and sex of responsible adult, $\quad(F=4.372, \mathrm{df}=\mathrm{I}, \mathrm{p}<0.05)$.

Table 6a: Distribution of children respondents by mean scores in English, S.D and ANOVA by sex of parent by level of education

$\begin{array}{ccccc}\text { Sex of } & \text { Highest level of } & \text { Mean } & N & \text { Std. Dev. } \\ \text { Parent } & \text { Education } & \text { Score } & & \end{array}$

\begin{tabular}{|c|c|c|c|c|c|}
\hline \multirow[t]{5}{*}{ Male } & & No formal education & 35.83 & 6 & 13.934 \\
\hline & & Primary education & 47.50 & 22 & 15.943 \\
\hline & & Secondary education & 51.74 & 46 & 12.702 \\
\hline & & Higher Education & 52.27 & 64 & 12.753 \\
\hline & & Total & 50.62 & 138 & 13.662 \\
\hline \multirow[t]{5}{*}{ Female } & & No formal education & 35.00 & 2 & 7.071 \\
\hline & & Primary education & 48.75 & 12 & 12.990 \\
\hline & & Secondary education & 53.50 & 30 & 15.09 \\
\hline & & Higher Education & 53.85 & 27 & 13.708 \\
\hline & Total & & 52.31 & 71 & $|4.27|$ \\
\hline Total & & $\begin{array}{l}\text { No formal education } \\
\text { Primary education } \\
\text { Secondary education } \\
\text { Higher Education } \\
\text { Total }\end{array}$ & $\begin{array}{l}35.63 \\
47.94 \\
52.43 \\
52.74 \\
51.19\end{array}$ & $\begin{array}{c}8 \\
34 \\
76 \\
91 \\
209\end{array}$ & $\begin{array}{l}12.082 \\
14.777 \\
13.626 \\
12.987 \\
13.86 \mid\end{array}$ \\
\hline
\end{tabular}

Table 6b: Distribution of children respondents by mean scores in Mathematics, S.D and ANOVA by sex of parent by level of education

$\begin{array}{lrrrr}\text { Sex of Parent } & \text { Highest level of Education } & \begin{array}{c}\text { Mean } \\ \text { Score }\end{array} & \text { N } & \text { Std. Dev. } \\ \text { Male } & \text { No formal education } & 33.67 & 6 & 14.376 \\ & \text { Primary education } & 45.91 & 22 & 18.234 \\ \text { Secondary education } & 48.91 & 46 & 16.122 \\ \text { Higher Education } & 51.09 & 64 & 20.538 \\ \text { Total } & 48.91 & 138 & 18.657\end{array}$




\begin{tabular}{|c|c|c|c|c|c|}
\hline \multirow[t]{5}{*}{ Female } & & No formal education & 30.00 & 2 & 14.142 \\
\hline & & Primary education & 50.00 & 12 & 16.787 \\
\hline & & Secondary education & 55.00 & 30 & 15.425 \\
\hline & & Higher Education & 57.59 & 27 & $|7.67|$ \\
\hline & Total & & 54.44 & 71 & 16.915 \\
\hline Total & & $\begin{array}{c}\text { No formal education } \\
\text { Primary education } \\
\text { Secondary education } \\
\text { Higher Education } \\
\text { Total }\end{array}$ & $\begin{array}{l}35.00 \\
47.35 \\
51.32 \\
53.02 \\
50.79\end{array}$ & $\begin{array}{c}8 \\
34 \\
76 \\
91 \\
209\end{array}$ & $\begin{array}{l}13.628 \\
17.591 \\
16.028 \\
19.859 \\
18.233\end{array}$ \\
\hline
\end{tabular}

ANOVA $-F=4.372, d f=I, p<0.05$

\section{Discussion}

The study confirms existing literature on educational performance which endorses parents' level of formal education as an important variable in the determination of children's performance. Parents with a high level of education tend to attach greater value to education than parents with low or no education. The higher value often translates to a willingness to commit more resources into children's education and provide other forms of support, which can enhance children's educational performance. Oloko (2003) noted that relatively educated parents tend to protect their children from work or provide remedial lessons for them while highly educated parents employ young domestics but keep their own children in school.

The study underscores the argument that certain support factors may interact with the gender of household head to make conditions different for children in his or her household. The factors which the study found important in the educational performance of children include children's regularity at school, amount of time children have to do homework, adults' supervision and discussion of children's studies, children's access to books and materials needed in school and parent's ability to pay school fees and other dues. Others are parents' income, time spent at work, time spent on domestic duties and time spent with children. It shows that women heading households prioritize their children's welfare including their education, so that the expectation of the society will not be fulfilled. This way, the women debunk the myth of poor performance readily associated with children in single-parent femaleheaded households. Female household heads show a commitment to their children's education through their supervision of their children's school work. Their ability to supervise their children however depends among other things on their level of education. If they had more time and more economic resources, they would be able to give their children better supervision. The implication of this is that there is the need to empower household heads if their children must access knowledge, which is an important measure of 
human development.

The study also shows that children's access to books and materials and regularity in school depend on the ability of the head of household to provide necessary assistance. Contrary to the stereotype that children in female-headed households are likely to have poor educational performance, the study shows that these children can perform just as well as children in other households. With the commitment of female heads of households, if their children could attend school more regularly and have all the essential materials, they would perform better than other category of children. This means that femaleheaded households are households in need of attention if their children must have opportunities for self actualization.

\section{Conclusion}

This study underscores the importance of education as a development issue. It also shows that the benefits of education are not limited to the immediate recipient but can be multiplied through the impact on the family of the recipient. This means that education is particularly important for mothers who spend more time with children and tend to have much influence on them. This point is further strengthened by the fact that children's educational performance increases with the level of education of their parents; with mothers' education in particular affecting children's education. The study questions the assumption that women heading households without partners are incapable of effective childrearing such that their children are expected to demonstrate poor performance in school. The study is about how the social construction of being male or female influences perceptions about household headship in relation to the education of children. The issues examined relate to female-headed and maleheaded households; but since women heading households tend to be single while men heading households tend to be married, the study invariably also encompasses issues involving single parent and two-parent families. The study is relevant to the development discourse in the sense that it involves issues of the quality of life of people, access to resources and children's educational performance. These are related to the three essential capabilities for human development which are for people to lead long and healthy lives, to be knowledgeable and to have a decent standard of living (UNDP 2004:13).

The study emphasizes the education of children. The right to education is one of the fundamental rights of a person. Knowledge, one of the dimensions of human development is measured by enrolment rates at all levels of education and adult literacy level. There is a positive correlation between education and development. The more developed a society, the more access people have to education and vice-versa. The significance of education is such that it influences the other two dimensions of human development. Education, through the prevention of diseases and sicknesses, can ensure long and healthy life, as well as provide access to a decent standard of living. Given its significance, men and women should have equal access to education at all levels. In principle, there is equal access to education for male and female but gender 
inequality manifests through the greater priority attached to male education in general. Gender inequality is a hindrance to human development in so far as it disempowers people from attaining these capabilities. The manifestation of gender inequality in one sector has implications for other sectors. The perception of female education as being of secondary importance relative to their traditional role of child bearers contributed to the low priority for female education. Ironically, maternal education improves the health of infants and children and ensures a better quality of life for household members. The education of women is closely associated with child mortality. The under-five mortality rate is more than twice as high for children of illiterate mothers as for children whose mothers have completed middle school (UNDP 2005:20).

The ability of household heads to provide support for their children's education affects and is affected by the country's level of progress towards the achievement of the first three Millennium Development Goals (MDGs) namely to eradicate extreme poverty and hunger; achieve universal primary education and promote gender equality and empower women. Nigeria is yet to achieve any of these three goals but attitude towards female education is changing and recent trends in enrolment into primary schools in Nigeria show consistent increase for both male and female. Primary school enrolment rate is however higher for boys (56\%) than that of girls (44\%). Completion rates for boys have been higher than that of girls. At the secondary level, enrolment rate is higher for males than females (National Planning Commis- sion 2005: 14, 19-20). Education can liberate from poverty and foster social mobility; so to eradicate extreme poverty and hunger, education must be prioritized. For female headed households which tend to be poorer, education and the acquisition of skills can help household heads to provide for their households, especially their children.

\section{References}

Articles in journals

Barros, R., Fox, L. \& Mendunca, R. (1997) "Female Headed Households, Poverty and Welfare of Children in Urban Brazil" Economic Development and Cultural Change Vol. 45, Number 2, Jan. 1997, pp. 23I-257.

Chindime, C. and Ubomba-Jaswa, S. (2007): 'Household Headship and Nutritional Status of Toddlers: An examination of Malawian Data'. African Population Studies 2 I (2) April 2007. Pp: 45-73. Union for African Population Studies.

Kennedy, E \& Peters, P (1992): 'Household Food Security and Child Nutrition: The Interaction of Income and Gender of Household Head', World Development Vol. 20, Number 8, 1992.

Nzegwu, N. (200I):'Gender Equality in A Dual-Sex System: The Case Of Onitsha' Jenda: A Journal of Culture and African Women Studies (200I). Accessed July 2, 2009 from http:// www.jendajournal.com/voll.I/ nzegwu.html

Oloko, S.B.A. (1993): 'Children's Street Trading in Nigeria as Adaptation and Maladaptation to Socio-Economic Circumstances' International Journal of Behavioural Development Vol. 16, 
No. 3, September, pp. 465-482.

Varley, A. (1996): 'Women Heading Households: Some more Equal than others?' World Development Vol. 24, Number 3, March 1996.

Published Books

Blumberg, R. L. and Kathreen Pethan (1994): 'The Intersection of Family Gender and Economy in the Developing World', International Year of the Family, Occasional Paper Series No. 9, 1994; Vienna: United Nations.

Bongaarts, J., (200I): Household size and composition in the Developing World. Population Council Working Papers Series. No. 144.

Buvinic, N. and Gupta, G. R. (1993): 'Responding to insecurity in the 1990s: Targeting woman-headed and woman-maintained families in developing countries'. Paper presented at the International Workshop on Insecurity in the 1990s: Gender and Social Policy in an International Perspective; April 1993, London: London School of Economics and European Association of Development Institutes.

Federal Office of Statistics (1996): 'The Nigerian Household 1995' Summary of results from the National Integrated Survey of Households (NISH); Lagos: Federal Office of Statistics, Federal Government of Nigeria.

Kimmel S. M with Amy Aronson (2000): The Gendered Society, New York: Oxford University Press.

Lengermann, P. M. and Niebrugge Brantley, J. (1993): 'Contemporary Feminist Theory' in Ritzer, G. (1993): Contemporary Sociological Theories $3^{\text {rd }}$ edition, New York:
McGraw-Hill.

National Population Commission (Nigeria). 2000. Nigeria Demographic and Health Survey 1999. Calverton, Maryland: National Population Commission and ORC/Macro.

National Population Commission (NPC) (Nigeria) and ORC Macro. 2004. Nigerian Demographic and Health Survey 2003. Calverton, Maryland: National Population

Commission and ORC Macro.

National Panning Commission (2005)

Nigeria: Millennium Development Goals 2005 Report. Abuja: NPC.

Oyewunmi, O. (1997): The Invention of Women: Making an African Sense of Western Gender Discourse, Minneapolis: University of Minnesota Press.

UNDP (2005) Summary Human Development Report 2005; International Cooperation at a Crossroads: Aid, trade and security in an unequal world. New York: UNDP

UNDP Nigeria (2004) HIV and AIDS: A Challenge to Sustainable Human Development. Human Development Report Nigeria 2004. Abuja: UNDP. United Nations (1995): Draft Platform for Action, Fourth World Conference on Women, 4-I5 September 1995, Beijing, China.

Chapters in edited collections

Ekejiuba, F. (1995): "Down to Fundamentals: Women-Centred Hearthholds in Rural West Africa." In Deborah Fahy Bryceson, ed., Women Wielding the Hoe: Lessons from Rural Africa for Feminist Theory and Development Practice. Oxford: Berg Publishers, pps. 47-63. Accessed July 2, 2009 from books.google.com.ng/books. 
Bakare-Yusuf, B. (2004): Yorubas Don't Do Gender: A Critical Review of Oyeronke Oyewunmi's The Invention of Women: Making an African Sense of Western Gender
Discourses. African Gender Scholarship: Concepts, Methodologies and Paradigms. CODESRIA Gender Series I, Dakar, CODESRIA, pp.6I-8I. 